Research.

\title{
THE EFFECT OF PROMOTION MIX OF THE OFF-AIR ENGLISH SERVICE PROGRAM AT RRI PRO2 FM BANDUNG UPON THE LOYALTY OF THE AUDIENCES
}

\author{
Indra Dermawan \\ Economic College of Ekuitas, Bandung, Indonesia \\ indra.der@gmail.com (I. Dermawan)
}

\begin{abstract}
Received: October 20, 2018; Accepted: November 19, 2018; Published: December 31, 2018
To cite this article: Indra Dermawan. The Effect of Promotion Mix of The Off-Air English Service Program at RRI Pro 2 FM Bandung Upon The Loyalty of The Audiences, The Management Journal of BINANIAGA, Vol. 03, No. 02, December 2018, pp. 01- 08.
\end{abstract}

\begin{abstract}
This research aims to figure out how the effect of promotion mix of the Off Air English Service Program (ESP) at RRI Pro2 FM Bandung upon the loyality of its audiences, in order to communicate the Off Air English Service Program (ESP) to the audiences of at RRI Pro 2 FM Bandung, RRI has been doing the activity of promotion mix. Referring to Kotler \& Armstrong (2008:166), promotion mix is also named Marketing Communication Mix, having the promotion mix the company could communicate the value of the audiences persuasively and develop the relationship with the customers. The writer has applied the theory of Kotler (2009:175) about the promotion mix (marketing communication mix) consisting of eight tools of promotion mix as the basic of the reseach which is promotion, marketing promotion, events and experiences, public relation and publicity, direct marketing, interactive marketing, mouth to mouth marketing, personal selling. Loyalty variable as $Y$ variable, the writer has applied the theory from Grifin (2002:31) the audiences loyalty consists of four characters: (1) makes regular repeat purchase, (2) purchases across products or services line, (3) recommends other products (refers other), and (4) demonstrates on immunity to the full of the competition. Griffin (2002:31). Result of the analysis in this research has applied the method of SEM analysis (Structure Equation Models) indicating that the promotion mix has significantly affected the loyalty of audiences which is $61.9 \%$, however the rest of $38.1 \%$ is the contribution of other variables that is not studied.
\end{abstract}

Key words: Promotion Mix, Loyalty of The Audiences.

\section{INTRODUCTION}

The promotion mix of the Off Air English Service Program at RRI Pro2 FM Bandung is one of the key factors of the success of the marketing program at RRI Pro2 FM Bandung, though the program is very good quality, but if nobody is listening to it and is not sure that the English Service Program (ESP) at RRI Pro2 FM Bandung will be useful for them, they will not listen or follow the Off Air program of English Service Program (ESP).

Promotion mix of the Off Air of English Service Program (ESP) at RRI Pro2 FM Bandung is a type of marketing communication spreading out the information, influencing, persuading, and or reminding the audience and the participant of the Off-Air English Service Program to accept, to listen and to be loyal to the program offered. 
The promotion mixes of the Off-Air English Service Program (ESP) at RRI Pro2 FM Bandung is the program of promotion mix executed by young creative people at RRI Pro2 Bandung as a place to express their fondness of English, however, even though, it is free of charge but the participants are less interested in. Actually, the requirement of English is badly required nowadays and it is one of the requirements to become a civil servant. According to the information, it is a must that civil servants have to speak English, the following table is the data of civil servants' recruitment.

Table 1.

Data of Civil Servants Recruitment Along With The Requirement of English Competency

\begin{tabular}{|l|l|}
\hline \multicolumn{1}{|c|}{ Civil Servant job opportunity } & \multicolumn{1}{c|}{ Competency } \\
\hline The Ministry of Law and Human Rights & Active English Language. Toefl 500 \\
\hline The Ministry of Internal Affairs & Active English Language. Toefl 450 \\
\hline The Ministry of Foreign Affairs & Active English Language, Toefl 500 \\
\hline The Ministry of Fishery and Maritime & Active English Language, Toefl 450 \\
\hline
\end{tabular}

Resources: www.menpan.go.id accessed on 3092015

The information about English language competency is taken from www.menpan.go.id which is the opportunity to remind the audience or participant about the promotion mix the Off Air English Service Program (ESP) at RRI Pro2 FM Bandung, this English program is provided free of charge for the people and is still not effective since the participants who have come to this program are not consistent and it is not indicating any improvement.

In order to make the audience loyal, an effective communication is required which is it has to be done by RRI Pro2 FM Bandung, one of the strategies done by RRI Pro2 Bandung to make the audiences loyal is producing the Off Air English Service Program (ESP) which is promotion mix to get the audiences and to make them loyal, that is why the writer is interested in the promotion mix of the Off Air English Service Program at RRI Pro2 Bandung to do a research.

The result of promotion mixed done by RRI Pro2 FM thru the Off-Air English Service Program (ESP) has indicated that the promotion mix is not yet effective because the participants who have come weekly are only a few and they have been decreasing each year. As a matter of fact, this program is given free of charge, and it is a crucial problem when people are not interested in a free of charge training.

\section{LITERATURE REVIEW}

"Promotion mix that we know is covering the activities of advertising, personal selling, marketing promotion, public relation, word of mouth information, direct marketing and publication" (Lupiyoadi, 2011:120)

Promotion is a marketing communication which is the marketing activity to spread out the information, to influence or to persuade and or to remind the people about the company and its products, however, they are expected to accept, to buy, and to be loyal to the products offered by the related company. (Hurriyati, 2010:58).

It has some consequencies. First, the customers of the service usually are relying on the story of words of mouth instead of advertisement. Second, they are relying on the price, persons in charge and physical appearance to examine the quality. Third, they are very loyal to the service provider who can make them satisfied. Service companies have three tasks, to improve different competition, service quality and productivity. (Sangadji, 2013: 98)

Indra Dermawan. The Effect of Promotion Mix of The Off-Air English Service Program at RRI Pro2 FM Bandung upon The Loyalty of The Audiences 
Characteristics of loyal customers / consumers referred to Griffin (2005) are as follows. Griffin (2005), loyal customers are the important assets of the company with the following characteristics:

1. Makes regular repeat purchase.

2. Purchases across the products or service line.

3. Recommends other products.

4. Demonstrats on immunity to the full competition for the similar products. (Sangadji, 2013, 105)

Valerie A. Zeithaml, Leonard Berry and A. Parasuraman (1996) quoted by (Lupiyoadi, 2011:203) mentioned that the factors motivating customers to be loyal are categorized as follows:

1. Communication from words of mouth

2. Willingness to buy

3. Price sensitivity

4. Complaint handling.

Referring to the aforementioned description, it has explained that the customers need the promotion mix of the service to make them loyal and to make a repeat purchase. Promotion mix of the Off-Air English Service Program done by RRI Pro2 FM Bandung is expected to create loyal audiences to listen to the RRI Pro2 FM Bandung, however it is the way how to improve English for the people and the most important thing is that this English program is free of charge.

\section{THE RESEARCH METHOD}

The following diagram below is describing the effect of promotion mix of Off-Air English Service Program at RRI Pro2 FM upon the loyalty of the audiences. The analysis has applied Structural Equation Modeling (SEM) analysis using software Smart PLS V.2.0 M3. And the following model will be presented in this research.

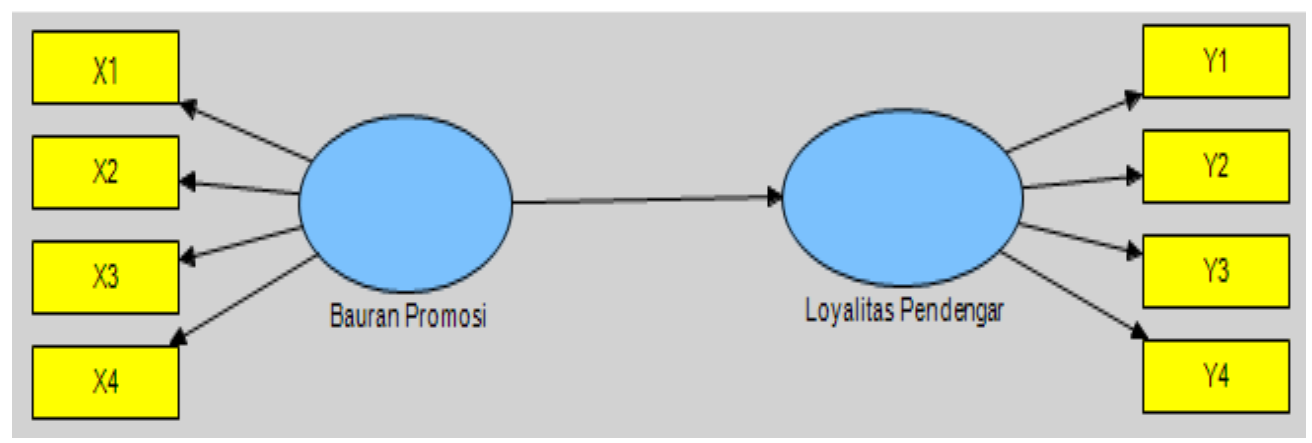

\section{Research Model}

Description of the diagram

$\begin{array}{ll}X & =\text { promotion mix } \\ X_{1} & =\text { Advertising } \\ X_{2}= & \text { Marketing promotion } \\ X_{3}= & \text { Public relation } \\ X_{4}= & \text { Information from words of mouth } \\ Y & =\text { Audience loyalty } \\ Y_{1} & =\text { Regular purchase } \\ Y_{2} & =\text { Purchase all products } \\ Y_{3}= & \text { Recommend other products } \\ Y_{4}= & \text { Immunity on other products }\end{array}$

Indra Dermawan. The Effect of Promotion Mix of The Off-Air English Service Program at RRI Pro2 FM Bandung upon The Loyalty of The Audiences 
Based on the design above, the research will be performed by the following steps to obtain good data either primary or secondary one and the writer has applied the data collection technique:

1. Literature Study

2. Field Study

By applying the following technique:

1. Interview as a direct communication technique to get additional data required and given to the participants who follow English Service Program at RRI Pro2 FM.

2. Direct observation upon the activities of Off-Air English Service Program has been done and to study the promotion and its effects upon the loyalty audiences at RRI Pro2 FM Bandung who follow English Service Program.

List of the questionnaires have been distributed to a hundred of respondents following Off Air English Service Program at RRI Pro2 FM Bandung.

\section{RESULTS OF THE RESEARCH AND THE DISCUSSION}

Latent variable of loyal audiences of Off-Air English Service Program (ESP) at RRI Pro2 FM Bandung has been created by the observation variables consisting of four dimensions; Regular repeat purchase (Y1), Purchasing at all lines (Y2), Recommend other products (Y3), Immunity of other products (Y4) to identify the significance of observation variables that has created the variable of loyal audiences upon Off Air English Service Program (ESP) at RRI Pro2 FM Bandung. Referring to the result above, it is indicated that overall the latent variable of loyal audience $(Y)$ is complied with the requirements of validity and reliability of model measurement. AVE and communality have obtained latent variable which is more than the standard of 0.5 , composite reliability and Cronbach alpha are at the minimum limit of 0.7 and loading factors for all manifest variables are bigger than the minimum limit of 0.7 . It has indicated that the loyalty of the audiences of Off-Air English Service Program (ESP) at RRI Pro2 FM Bandung has been affected by the promotion mix of Off-Air English Service Program (ESP). In detail the feedback of respondents to make a repeat purchase has demonstrated that the participants of Off-Air English Service Program (ESP) at RRI Pro2 FM Bandung will be back to follow the Off-Air English Service Program (ESP) which is it is indicating the loyalty of the audiences.

Furthermore, the respondents' feedback of the participants of Off-Air English Service Program (ESP) at RRI Pro2 FM Bandung indicating that they will participate the Off-Air English Service Program (ESP) which is 14\% respondents replied neutral, 50\% agree and $36 \%$ the most agree. Based on the feedback aforementioned resulting the actual score of 422 indicating that the participants will be following a routine Off Air English Service Program (ESP) at RRI Pro2 FM Bandung and it is indicating the loyalty of the audiences of Off-Air English Program (Esp.) at RRI Pro2 FM Bandung.

Feedback of the respondents' evaluation in the purchasing of across products and services lines, they declare that they will participate the other off-air program instead of the Off-Air English Service Program (ESP) at RRI Pro2 FM Bandung which is $4 \%$ of the respondents disagree, $31 \%$ neutral and $47 \%$ agree and $18 \%$ the most agree indicating that the loyalty of audience upon the Off-Air English Service (ESP) at RRI Pro2 FM Bandung.

Respondents' feedback about the willingness to recommend other products at RRI Pro2 FM Bandung to other people has resulted $36 \%$ neutral, $45 \%$ and $19 \%$ the most agree. Based on the feedbacks above, it is indicating that actual scores of 383 who are ready to recommend DJ School on the Air at RRI Pro2 FM to other people. The last feedback of the audience's loyalty has indicated the immunity of other English

Indra Dermawan. The Effect of Promotion Mix of The Off-Air English Service Program at RRI Pro2 FM Bandung upon The Loyalty of The Audiences 
conversation program instead of at RRI Pro2 FM Bandung, the result of analysis has obtained the following feedbacks of the respondents.

Feedbacks of the respondents regarding the immunity against the other products, $7 \%$ of the respondents replied the most disagree, $24 \%$ disagree, $26 \%$ neutral, $27 \%$ agree and $16 \%$ the most agree. The actual scores of 321 has indicated that the participants are not going to follow the Off-Air English Service Program (ESP) unless at RRI Pro2 FM Bandung.

\section{Diagram 2 - Coefficient of Structural and Correlation Path}

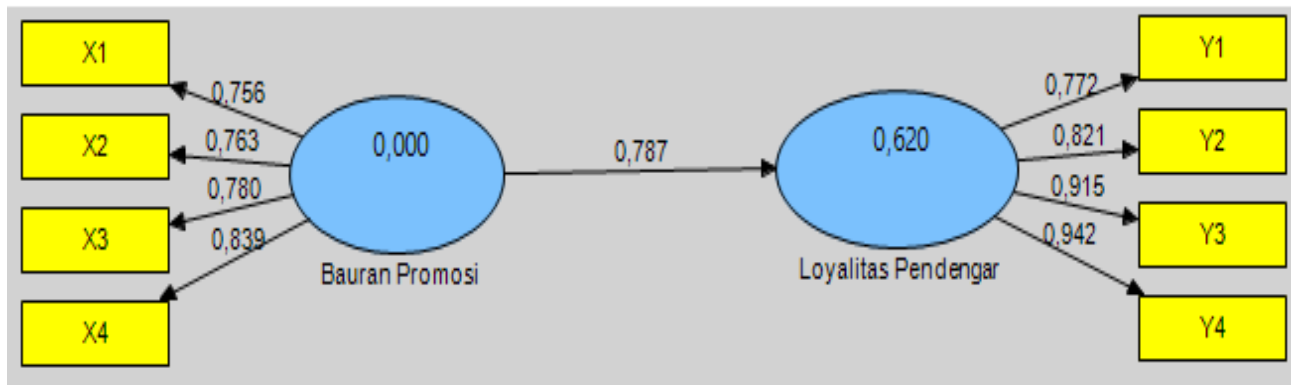

Resource: The processed result using Software Smart PLS 2.0 M3

Based on the result of inner model above, it has indicated that the correlation value of 0.787 . For the Coefficient path with one dependent variable, the path coefficient value is the same with the correlation value. R-square value obtained from the result of quadrant correlation coefficient is $(0.787)^{2} \times 100 \%=61.9 \%$. It can be concluded that the promotion mixes of Off-Air English Service Program (ESP) at RRI Pro2 FM Bandung has contributed the effect upon the loyalty of the audiences of $61,9 \%$, but the rest of $38.1 \%$ is the contribution of other variables which is not studied.

In order to identify whether the promotion mix of Off-Air English Service Program (ESP) at RRI Pro2 FM Bandung has affected the loyalty of audiences, a hypothesis test has been done using the hypothesis formulation as follows:

$\mathrm{H}_{0}$ : Means that promotion mix of Off-Air English Service Program at RRI Pro2 FM Bandung has not significantly affected the loyalty of audiences.

$\mathrm{H}_{1}$ : Means that promotion mix of Off-Air English Service Program at RRI Pro2 FM Bandung has significantly affected the loyalty of the audiences.

In order to reply the hypothesis above, table 4.3 has indicated t-count value of 23.702. This value is bigger than t-table of 1.960 . So that it can be concluded that promotion mix of Off-Air English Service Program at RRI Pro2 FM Bandung has significantly affected the loyalty of audiences.

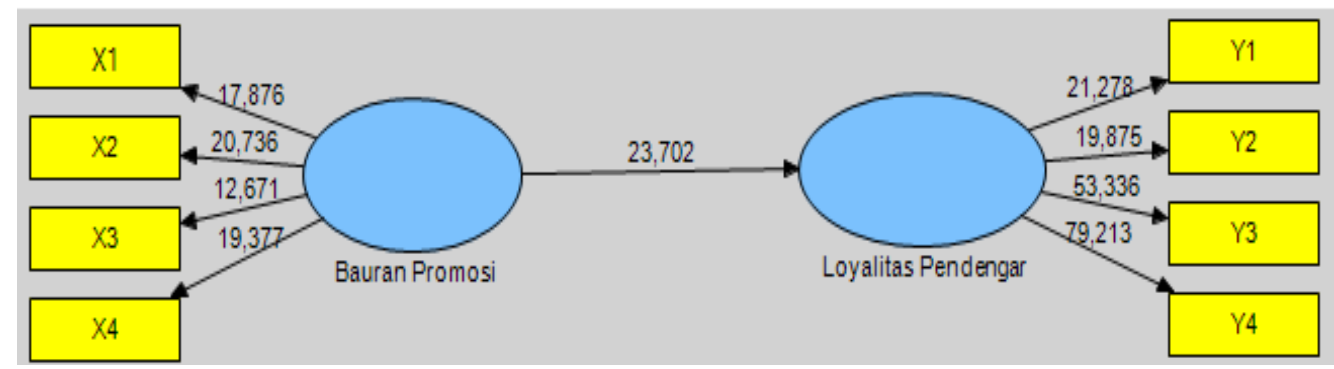

Resource: Processed Result of the researcher using Software Smart Pls.2.0 M3

Figure 1.

Test result of the effect of promotion mix upon the loyalty

Indra Dermawan. The Effect of Promotion Mix of The Off-Air English Service Program at RRI Pro2 FM Bandung upon The Loyalty of The Audiences 
Referring to the diagram above, $t$-count of 23.702 is bigger than t-table of 1.960 , and it can be concluded that the promotion mix has significantly affected the loyalty of audiences.

\section{CONCLUSION AND SUGGESTIONS}

\section{Conclusion}

Based on the result of data analysis and the description which have been done, the writer has concluded that the promotion mixes of Off-Air English Service Program (ESP) at RRI Pro2 FM Bandung has affected the loyalty of audiences of $61.9 \%$ contribution, and the rest of $38.1 \%$ contribution of the other variables that has not been studied.

1. The advertising has significantly affected the loyalty of audiences which is $-8.3 \%$ contribution.

2. Marketing promotion has significantly affected the loyalty of audiences which is $26.3 \%$ contribution.

3. Public relation has significantly affected the loyalty of audiences which is $24.6 \%$ contribution.

4. Information of words of mouth has significantly affected the loyalty of audience which is $31.2 \%$ contribution.

In this research the most significant effect that can increase the loyalty of audiences of Off-Air English Service Program (ESP) at RRI Pro2 FM Bandung is the variables of marketing promotion and the information of words of mouth, and these variables have given the biggest effect upon the loyalty of audiences of Off-Air English Service Program (ESP) at RRI Pro2 FM Bandung.

\section{Suggestions}

1. It should have to execute further research regarding the other factors affecting the loyalty of audiences RRI Pro2 FM Bandung, what kind of the factors that have been affecting the loyalty of audiences instead of the effect of promotion mix of Off-Air English Service Program (ESP) which can improve marketing science and get deeper knowledge whether anything given free of charge will create loyalty and increase the sales.

2. Based on the research done by the writer, he has noticed that the promotion mix of Off Air English Service Program (ESP) at RRI Pro2 FM Bandung has been done very good and affected simultaneously and partially the audiences to be loyal, however it is still to be improved and to add more advertising contents, place the advertisement on other media such as banner, billboard, etc to ease the audiences and participants getting more information about the English Service Program (ESP) at RRI Pro2 FM Bandung.

3. Regarding the public relations, it needs to be reviewed about partnership with other party which is related to the public relation activities at the Off-Air English Service Program which are not running quite well, because the existing activities is concentrating only to the speaking ability of the audiences who are being the participants of the program.

\section{REFERENCES}

Alma, B. (2003). Enterpreneurship, Alfabeta. Bandung.

.(2004). Marketing and Service Marketing Management, Alfabeta, Bandung.

.(2011). Marketing and Service Marketing Management, Alfabeta, Bandung.

Indra Dermawan. The Effect of Promotion Mix of The Off-Air English Service Program at RRI Pro2 FM Bandung upon The Loyalty of The Audiences 
Kotler, P. and Amstrong, G. (2011). Marketing Principles, Erlangga, Jakarta.

Belch, GE and Michael. (2004). Advertising and Promotion: And Integrated Marketing Communication Perspective, Mc Graw-Hill//rwin, Ney Jersey.

Christin, M. (2010). The Effect of Promotion Mix upon The Students' Decision, Theses, Universitas Padjadjaran, Bandung.

Cresswell, J. C. (2010). Research Design, Pustaka Pelajar, Yogyakarta.

Yudhiartika, D. and Haryanto J. O. (2012). The Effect of Personal Selling, Display of Marketing Promotion upon Brand Awareness and The Intention to Buy Ponds Cosmetic Product, Buletin Studi Ekonomi.

Gozhali, I. (2011). Application of Multivariate Analaysis Using IBM SPSS 19 Program, UNDIP, Semarang.

Haryanto, R. A. (2013). The Strategy of Products Quality Promotion, Service Quality upon The Customer Satisfaction at MCDONALD Restaurant Manado, Jurnal Riset Ekonomi, Manajemen, Bisnis, dan Akutansi.

Hernawati, L. (2012). The Connection between Promotion and The Image of RRI Bandung, Theses, Unisba, Bandung.

Hurriyati, R. (2010). Marketing Mix and The Loyalty of Consumers, Ikapi, Bandung.

Kotler, P. and Kevin, L. (2009). Marketing Management Book 1 \& 2, $13^{\text {th }}$ Edition, Erlangga, Jakarta.

Kotler, P. (1995). Strategic Marketing for Non Profit Organizations, Third Edition, Gadjah Mada University Press, Yogyakarta.

Kurtz, L., Kenneth., and David,. (1998). Service Marketing, John Willey \& Sons, New York.

Lane, Kotler, P., and Kevin. (2009). Marketing Management, Book $1 \& 2.12^{\text {th }}$ edition, Eralngga, Jakarta.

Erlangga, Jakarta.

(2009). Marketing Management Book 1, $12^{\text {th }}$ edition, (2009). Marketing Management, Book 1, $13^{\text {th }}$ edition, Erlangga, Jakarta.

Limakrisna, N. (2008). The Effect of Promotion and Clients' Relationship upon The Loyalty of Clients, Jurnal Ekonomi Bisnis.

Lupiyoadi, R. (2011). Service Marketing Management, Salemba Empat, Jakarta.

Riduan. (2008). Method and Technic of Thesis Preparation, Alfabeta, Bandung: Alfabeta. (2005). Measuring Research Variables Scale, Alfabeta, Bandung. 
The Management Journal of BINANIAGA Vol. 03, No. 02, December 2018

PISSN: $2527-4317$

EISSN: $2580-149 x$

Rombe, E. (2009). Loyalty of The Customers and The Variables Affecting it, Unpad, Bandung.

Segoro, W. (2011). The Effect of The Perception about The Service Quality as Dependent Factors and The Quality of Relationship upon The Satisfaction and Loyalty of Customers, Jurnal Telekomunikasi dan Komputer.

Sopiah, E. M. S. (2013). Consumer Behaviour, Andi, Yogyakarta.

Sriwendiah, S. (2012). The Effect of Promotion Mix upon The Decision of Consumers Family Migration, Theses, Unpad, Bandung.

Sugiyono. (2011). Statistics for The Research, Alfabeta, Bandung.

Sumantri, S. (2012). Consumers Behaviour, Why People Want to Buy, Quantum Quality, Jakarta.

Sutisna. (2011). Consumers Behaviour and Marketing Communication, PT. Remaja Rosdakarya, Bandung.

Tjiptono, F. (2002). Marketing Strategy, Andi, Yogyakarta.

Zethmal, A., Valerie., and Marry, J. B. (2000). Service Marketing. Mc Graw Hill, New Jersey.

http://www.panselnas.menpan.go.id ( 3092014).

http://www.facebook.com (3092014).

http://www.rri.co.id (3092014).

http://www.radioclinic.com (30092014).

Indra Dermawan. The Effect of Promotion Mix of The Off-Air English Service Program at RRI Pro2 FM Bandung upon The Loyalty of The Audiences 